\author{
УДК 330.322:336 \\ JEL B400 \\ DOI https://doi.org/10.17721/tppe.2019.39.6
}

Kateryna Akulenko, Ph.D. Student

Taras Shevchenko National University of Kyiv

\title{
ANALYSIS OF FOREIGN EXPERIENCE OF INCREASING THE INVESTMENT ATTRACTIVENESS OF ENTERPRISES
}

Conceptual approaches of determining the economic essence of the concept of investment attractiveness of the enterprise are investigated. The advantages and main disadvantages of the existing concepts of the investment attractiveness of the enterprise are identified. The several groups of existing approaches to definitions of the concept of investment attractiveness of the enterprise as domestic and foreign scientists are highlighted. In particular, a factorial, internal and comparative approach to the study of investment attractiveness of enterprises is considered. The own classification of conceptual approaches to determination of essence of investment attractiveness of the enterprise is offered, the structure of which is supplemented in particular by the characteristics of the enterprise from the perspective of its development prospect and the presence of social and psychological factors. The concept of investigation of the essence of the investment attractiveness of the enterprise is supplemented and generalized. The experience of developed foreign countries on the issues of formation of investment attractiveness of enterprises, as well as industries and regions in general are analyzed. In particular, the foreign experience of increasing of investment attractiveness in the example of the USA and China is generalized and the cluster strategies used in European countries are considered.

Keywords: investments, investment attractiveness, investment efficiency, investor satisfaction, foreign experience of investment support, cluster model.

The purpose of the research is a development of directions of increasing the international investment "image", which is very important for attracting foreign direct investment in the country as a whole, and for investing economic activity of enterprises in particular. In order to create a favourable investment environment for the enterprise, first of all it is necessary to create a comprehensive system by the State to ensure its investment attractiveness on the world stage.

As the international experience shows attracting foreign investments by enterprises has a positive impact on the economy of the country and the rational use of foreign investment contributes to improve the competitiveness of production of enterprises in the world market, development of production, productivity growth, transfer of advanced technologies and job creation, etc. Therefore studying of foreign experience of increasing the investment attractiveness of enterprises is becoming more and more important, as it gives the opportunity to gain experience in creating a complex of favorable conditions for investment, which, in turn significantly increases the role of enterprises in the development of investment activities.

The findings of the study. Issues related to the analysis and study of the experience of investment attractiveness of foreign enterprises were investigated in the works of many domestic and foreign scientists, in particular such as: M.M. Bilousova, A.V. Biryukov, G.L. Voznyuk, A. G. Goncharuk, V. M. Goncharov, T. G. Zatonatska, K.M. Kramarenko, O.V. 
Pimenova, Yu.M. Popova, T.N. Sedash, B.M. Smitienko, O.V. Tarasenko, O.N. Ustyuzhina, G.M. Filyuk, A.I. Chervanov, N.I. Shevchenko, S.V. Yukhimchuk and others.

Remaining part of the task. Disregarding the sufficiently deep studies of these issues, some aspects of it have not yet been resolved, including those relating to the development of conceptual approaches of determining the nature of the investment attractiveness of the enterprise and the directions of using foreign experience in formation of high investment attractiveness of enterprises. That's why remain debatable task need further research.

The aim of the study is to study and generalize through the prism of conceptual approaches to the economic essence of the concept of investment attractiveness of the enterprise, foreign experience of increasing the investment attractiveness of enterprises with the purpose of its implementation to domestic realities.

Research Methodology. In the process of research, the following methods were used: methods of comparison, analysis and synthesis is used in determining of the features of conceptual approaches to the concept of investment attractiveness of an enterprise and the formation of author's definition of this category; method of diagnostic evaluation is used in evaluation of existing models for analyze of the investment attractiveness of enterprises; the method of graphic construction is used within constructing of figures of Conceptual approaches and formation of investment attractiveness of enterprises in foreign countries.

Results of the study. Given the high importance of investment for the development of domestic enterprises, it is necessary to start the research with a generalization of modern approaches to the essence of the investment attractiveness of the enterprise. The analysis of the existing definitions of the concept of investment attractiveness of the enterprise by domestic and foreign scientists made it possible to distinguish several groups of approaches that were formed in the economic literature by combining certain features. Let's look at them in more detail.

Investigation of investment attractiveness through a set of factors of internal and external environment, that influence the final decision of the investor to invest in the enterprise [1, p. 31]. This approach examines the investment attractiveness of the enterprise by applying the tools of factor analysis of the internal and external environment of the enterprise. The advantages of this approach are the coverage of all areas of activity of the enterprise that require valuation for the investor: financial and economic, marketing, social, logistical, administrative, legal, technological, etc.

However, this approach also has its disadvantages because the large number of valuation factors does not allow to assess the state of the enterprise unequivocally, since the influence of the factors are expressed in the relationships and mutual influence of the factor indicator on the resultant, that is, for the assessment of the enterprise from the point of view of the factor approach can be selected only a small number of indicators, the interpretation of the impact on which will not give a complete understanding of the situation in the enterprise. Considering the greater number of performance indicators is related with a high complexity of the evaluation process itself and the lack of uniform criteria. Considering the greater number of performance indicators causes the high complexity of the evaluation process itself and it could have the lack of uniform criteria. 
The lack of established indicators and evaluation criteria within the factor approach, led to the emergence and dissemination in the scientific literature of an integrated approach to determine the essence of investment attractiveness of enterprises [3, p. 101]. Thus, the integral approach determines the innovative attractiveness of the enterprise by its integral characteristics both by means of a single integral indicator and by means of a complex system of integral indicators.

The application of this approach is more acceptable for assessing investment attractiveness but has the opposite disadvantage compared to the previous approach: it is practically impossible to determine the nature of the influence of certain conditions and factors on an object of economic activity, operating with only one or more generic indicators. The use of this approach is only advisable in the context of a comprehensive assessment or at the same time as another approach.

By comparative approach, the investment attractiveness of the enterprise is considered as its relative characteristic, since the studied enterprise is evaluated as one of the options for future investment. According to this approach, a system of the score marksand rating is used for the analysis, however, the possibilities of applying this approach are very limited due to the lack of reliable and comparable information regarding the internal environment of the competing enterprises. In addition, investment attractiveness is a relatively diverse relative concept, and, for example, what may be attractive to some investors is not always attractive to others.

In my opinion the approaches analyzed need to be expanded and supplemented as they have several disadvantages:

1. In a large number of existing definitions, the investment attractiveness of an enterprise is related solely to the system of financial and economic performance of the enterprise, without taking into account the equally important socio-psychological factor.Whereas even the name of the term "investment attractiveness of the enterprise" includes a socio-psychological element in the form of the concept of "attractiveness", which is widely used in economic literature;

2. The necessity to take into account the requirements of potential investors, which logically follows from the first. The personal view of the potential investor is very important to the state and condition of entity being considered for investing. It has to be able to satisfy the investor's economic or social effect expectations, when choosing an entity for investing his capital. We believe that this aspect is key in defining the concept of investment attractiveness of the enterprise;

3. It is necessary to achieve consistency and symbiosis between the evaluation of financial, economic, social and psychological, production, innovation, environmental and other factors that in the complex form the investment attractiveness of the enterprise. Thus, underestimating or overestimating the role of one in comparison to other factors can lead to distortions of evaluation activities and a holistic view of the company;

4. The biggest mistake in assessing the investment attractiveness of an enterprise that investors can assume is not taking into account the company's development prospects. The choice of investment objects should be based on the broadest and most favorable prospects for development, as well as taking into account the conditions and 
action of the environment and its dynamic change. This indicates the necessity of taking into account the prospects of development of the enterprise in determining its investment attractiveness;

5. The necessity to get the opposite effect. So it is not only the investor who has the economic or social effect of investing,the effects of investing should be positive also for the object of investing, whereas, for example, an investor may only be interested in the property complex of the enterprise, thereby destroying its technological, production and personnel potential.

6. The use in some definitions of the investment attractiveness of an enterprise the expression "high level of profit of investment with minimal risks" is partially incorrect since obtaining high profit implies a certain degree of risk and every investor knows it, therefore, low risk and high profitability of the project may cause at the investor an opposite response, that is, alert rather than attract;

7. Investment attractiveness is shaped by the competitiveness of products, consumer orientation, which is expressed in the fullest satisfaction of their requests. Therefore, the level of involvement of innovations in the activity of the enterprise within the framework of the use of investment capital is very important for enhancing the investment attractiveness of the enterprise;

8. The focus of almost all definitions only on high financial and economic indicatorswhich depending on the situation, may not always be correct, since considering the enterprise from the point of view of attractiveness for venture investment or conducting mergers or acquisitions implies a little importance, for example, low indicators of its financial condition.

Summarizing all the above approaches, we propose our own classification of conceptual approaches to determine the essence of the investment attractiveness of the enterprise, the structure of which is presented in Figure 1.

Thus, the multifaceted character of the concept of "investment attractiveness of the enterprise" is confirmed by our proposed classification of concepts, which allowed us to distinguish in addition to the already existing features, on the one hand, characteristics of the enterprise from the perspective of its development, both financial and production, market value which made it possible to integrate the economic interests of investors, enterprise and other stakeholders into one.

On the other hand, the proposed concept of economic and psychological investor satisfaction allows to emphasize the presence of socio-psychological factors in the investment decision making process, which neglect can lead to significant miscalculations in assessing the investment attractiveness of business entities. 


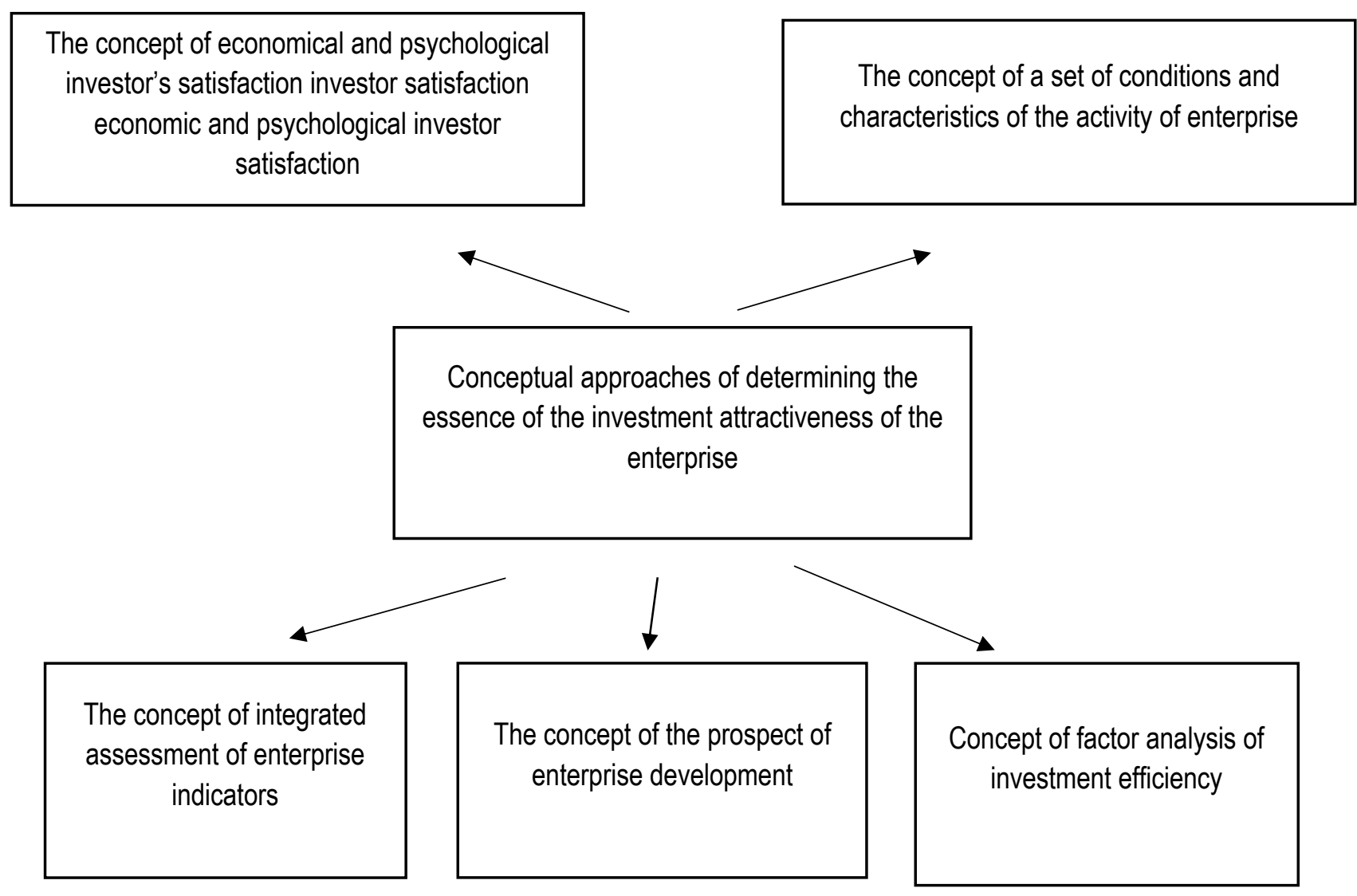

Figure 1. Conceptual approaches to determining the essence of the investment attractiveness of the enterprise.

Note. Formed by the author on the basis of copyright research materials

Investment attractiveness is an integral characteristic, which includes the investment climate, the level of investment infrastructure development and the ability to attract investment resources that significantly affect the formation of investment profit as well as the level of investment risk. The investment attractiveness of the environment of the enterprise (region, industry, country) has an indirect impact on the investment attractiveness of the enterprise, first, because the enterprise is an open system, and secondly, because external factors have an universal character and play for potential investors no less important role than a particular object of investing.

Analyzing the investment attractiveness at these levels is the main stage of forecasting and anticipating measures to attract investment resources and increase the attractiveness of investment objects.To pass this stage effectively it is necessary to research and summarize the experience of developed foreign countries on the issues of formation of investment attractiveness of enterprises, as well as industries and regions in general.

The results of the study of the foreign experience of forming the investment attractiveness of the enterprise are presented in Figure 2.

The high level of competitiveness of the US economy reached mostly due to the fact that stimulating the inflow of investment in science and in the development of new 
technologies is one of the key functions of government at all their levels. The state incurs about half of the Research and development expenditures, and finances more than half of all basic research. The remaining funds are provided by private corporations, universities and foreign investors, whose contribution is also significant [6]. This is due to the fact that the development of investment potential of individual states and the country as a whole has always been identified as one of the key areas of activity of authorities at all levels.
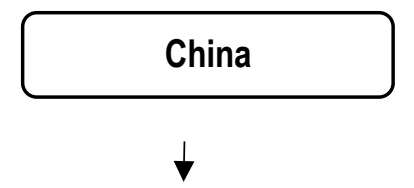

Special economic zones were created, which were characterized by a liberal tax regime and significant relief of administrative barriers

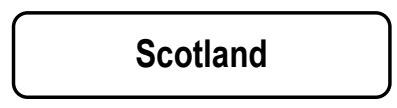

Development of clustering processes of economic space through the creation of networks of local companies that coordinate the formation of economic infrastructure of the

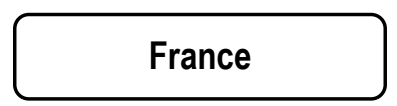

Cluster policy is implemented in the form of formation of poles of competitiveness, intended to unite business, scientific community and institutes of education.

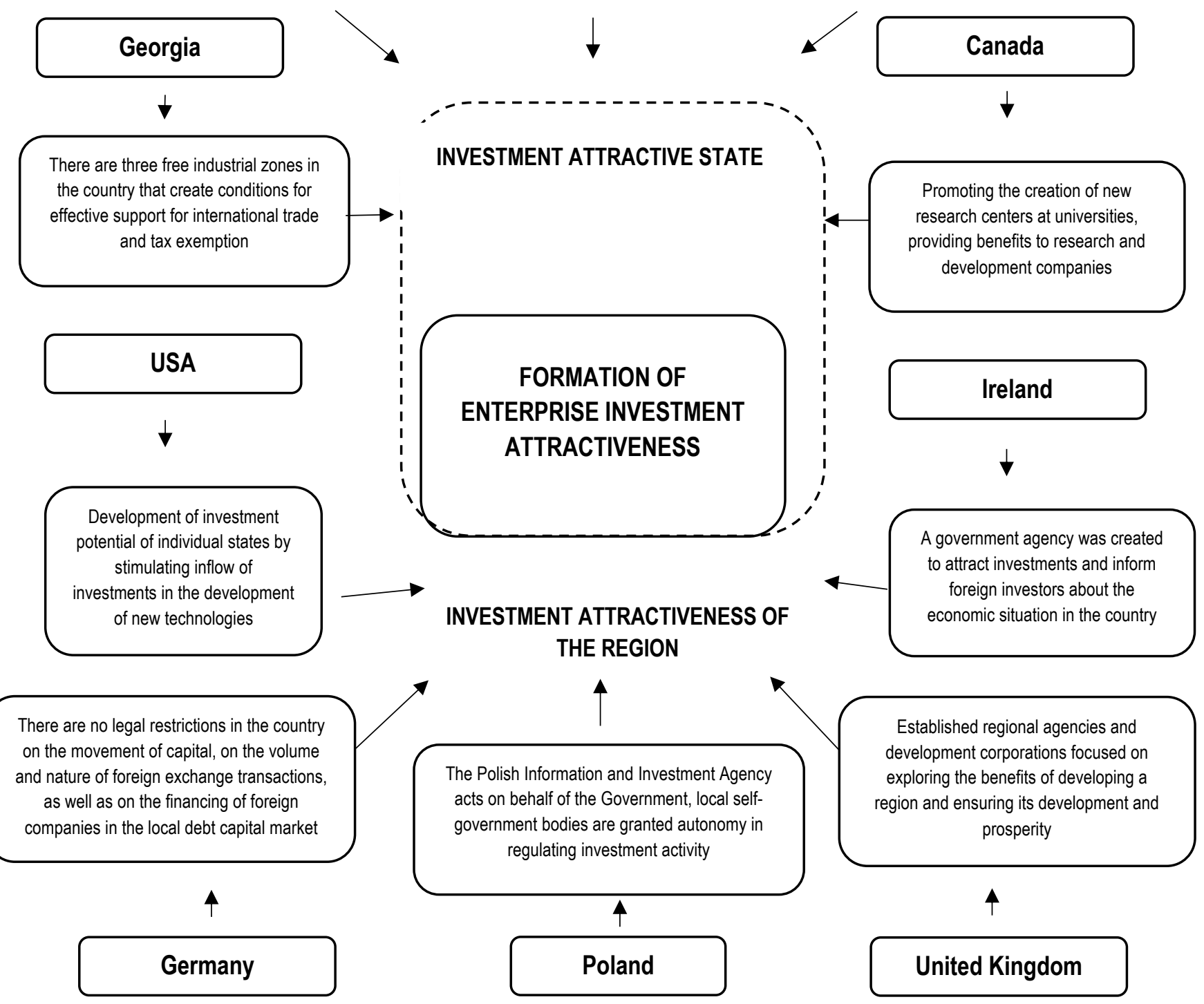

Figure 2. Foreign experience of formation of investment attractiveness of enterprises

Note. Formed by the author on the basis of copyright research materials 
The methods used in the United States at various levels of government to develop the state's investment potential can be roughly divided into three groups: direct financial incentives (providing grants, loans and credits by state's government, financing of research and development funding); indirect financial incentives (tax incentives, discounts, investment tax credits); non-financial incentives (infrastructure development, transparent information policy).

State authorities are creating differentiated conditions for different investors depending on the value of the proposed investment projects.

Attracting foreign investors to the country is a particular importance. Currently, local authorities are offering more than 6,000 programs to stimulate economic development, which will provide a wide range of benefits for foreign investors. These privileges are granted within specially created "business zones", which already number comes to around 1,300 .

In China, there are benefits for joint ventures to encourage investment attractiveness, which typically include:

- release from income tax for 5 years after the beginning of its activity;

- the right of duty-free import of raw materials and means of production;

- the right of free export abroad of profits, interest and dividends.

Special economic zones have been created in China, which are characterized by a liberal tax regime and significant relief of administrative barriers when starting a new business.

The Chinese government has also invested in so-called "export networks." These are mainly priority sectors of the economy (in particular, light industry and electronics,) which have been allocated subsidies for the modernization of factories and the purchase of raw materials. The purpose of the program is to improve the quality and increase the quantity of Chinese export goods. "Networks" of companies controlled by foreigners more than $25 \%$ were granted special privileges and access to loans from the Central Bank of China.

Currently, such companies produce more than $80 \%$ of Chinese exports. In addition, China has established a clear system for informing foreign investors about investment opportunities in the country and contacts with potential partners. [5, c.60].

One of the most successful cluster models among all European countries is the structure created in France. Cluster policy in this country is realized in the form of formation of so-called poles of competitiveness created to unite business, scientific community and institutes of education. The French poles of competitiveness are divided into "regional", "European" and "international." It should be noted that the French Investment Agency particularly supports the participation of foreign investors in cluster structures, helping them to find the most attractive projects. In addition, foreign companies are often involved in carrying out certain scientific researches. An important feature of the development of cluster models in foreign countries is that within the clusters created, support is provided not only to big business, but also to medium and small enterprises, which are assigned a supportive and service role. So, this form of organization of economy becomes attractive 
to investors not only of different types, but also of "scale". This makes it effective and its implementation promising [5, p.61].

In Scotland, improving the investment climate is also characterized by the development of clustering processes in the economic environment. The creation of integrated enterprises and the training for those specialists are carried out through the creation of networks of local companies (the Local Enterprise Companies - LECs,) which coordinate the formation of economic infrastructure of the territory, including administrative, accounting help, real estate services, marketing, creation of investment programs, land protection [7, c.93].

In Canada, an important area of activity which support improvment of investment attractiveness is to promote the creation of new research centers at universities. At the same time the Government's activities are focused on providing privileges to the companies which carry out scientific research and development. The tax benefits program for scientific research and experimental development provides companies with a direct and complete write-off of most expenses, as well as tax credits of 20 - 35\% [7, p.93].

An important role in formation of the investment attractiveness of UK businesses belongs to regional development agencies and corporations of development, which include the Scottish and Welsh Development Agencies, the London Docks and river Meisser Development Corporations. These organizations focus on exploring the benefits of developing a region to ensure its further continued development and prosperity. In order to facilitate investment promotion in the UK, European Investment Bank loans are granted on preferential terms, reaching up to $50 \%$ of fixed capital investment $[9$, c. 141].

In Poland, state structures play an important role in formation of investment attractiveness. For example, the Polish Agency for Information and Investment operates on behalf of the Government in Poland. It should be noted that local authorities are given autonomy in regulating of investment activity. These measures attract investors and ensure the implementation of strategic directions for the country's development.

In Germany, there are no legal restrictions on the movement of capital in order to increase investment attractiveness. The volume and character of foreign exchange transactions, and also on the financing of foreign companies at the local borrowing market, these features are confirmed by the Law on Foreign Economic Relations and the Law on Loans. However, licenses are required to operate in some sectors of the economy, in particular: medical, pharmaceutical, insurance, transportation, hotel and restaurant business and banking [4].

In Ireland has been set up state agency, it's called the Industrial Development Agency of Ireland which is involved in attracting investments.

The agency also lobbies for policies that help to attract foreign investment (for example, Ireland has one of the lowest taxes on trade in Europe - 12.5\%) and informs foreign investors about the economic situation in the country. Particular efforts are being made to attract investment in high-tech industries where investors are offered favorable tax conditions. The Agency also provides assistance to economically backward areas of the country by providing special privileges for investors who open branches of their enterprises in them [7, p.94]. 
There are three free industrial zones in Georgia that create the conditions for effective international trade support and are subject to a tax exemption regime for international companies. The Free Industrial Zones law was adopted in 2007 to encourage investments to country, as well as the development of international trade and transit activities. The favorable conditions of taxation and customs control that operate in free industrial zones create incentives to move their production facilities to foreign companies, which has facilitated the growth of industry by providing new opportunities for investment in such fields as: petrochemical industry, metallurgy, automotive, electronics, pharmaceuticals , production of building materials [2, p.8].

Conclusions. The study of foreign experience of formation of investment attractiveness of the enterprise allowed to identify the following features. Stimulation of investment activity characteristics for the developed countries. The creation of institutions focused on exploring the advantages of the region and ensuring its further development. Removal of legal restrictions on the movement of capital on the volume and character of foreign exchange transactions, as well as on the financing of foreign companies on the local borrowing market. This would give to local self-government bodies autonomy in regulating investment activity. Creation of state agencies that are engaged in attracting investments and informing foreign investors about the economic situation in the country. Stimulating inflow of investments in the development of new technologies; facilitating the creation of new research centers at universities; providing benefits to companies which carry out scientific research and development. The creation of free industrial zones to effectively support tax-exempt international trade. The development of economic clustering processes through the creation of companies that coordinate the formation of economic infrastructure of the territory; significant relief for administrative barriers.

Thus, the generalization of foreign practices to promote the development of investment attractiveness allows to indicate that the effective attraction of investment is determined by the innovative character of production. Also priority areas of investment in developed countries are those that allow you to achieve rapid return on investment and at the same time cause the appearance of necessity for the development of interconnected industries.

\section{References}

1. Goncharov V. M. Investy`cijna pry`vably' vist` pidpry`yemstva: sutnist` ta faktory` vply`vu / V. M. Goncharov, M. M. Bilousova // Naukovi praci Poltavs'koyi derzhavnoyi agrarnoyi akademiyi. Ser.: Ekonomichni nauky'. - 2012. - Vy’p. 4. - Tom 3. - S. 31-35.

2. Zatonacz 'ka T. Svitovy j dosvid formuvannya derzhavnoyi investy 'cijnoyi polity 'ky' ta mexanizmiv yiyi realizaciyi / T. Zatonacz`ka // Visny’k Ky’yivs'kogo nacional'nogo universy`tetu imeni Tarasa Shevchenka. Ekonomika. - 2014. - Vy’p. 8. - S. 6-10.

3. Kramarenko K. M. Investy' cijna pry`vably'vist' pidpry'yemstva ta metody'chni pidxody do yiyi vy`znachennya / K. M. Kramarenko // Pry'chornomors`ki ekonomichni studiyi. - 2016. - Vy`p. 10. - S. 101104.

4. Popova Yu.M. Svitovy`j dosvid regulyuvannya mizhnarodnoyi investy’cijnoyi diyal'nosti / Yu.M. Popova, O.V. Tarasenko// Global'ni ta nacional'ni problemy' ekonomiky' - 2017. - \# 16. [Electronic resource] - Access mode: http://global-national.in.ua/issue-16-2017 
5. Sedash T.N., By'ryukov A.V. Y'spol'zovany'ezarubezhnogooputa dlya povbsheny'yakonkurentosposobnosty' y' y'nvesty' cy'onnojpry' vlekatel'nosty' rossy' jsky 'xregy onov I T.N. Sedash, A.V. By'ryukov // Fy'nansы y` kredy`t. - 2013. - \# 38. - S. 59-65.

6. Smy'ty'enko B.M. My'rovayaэkonomy'ka: uchebny'k dlya akademy'cheskogobakalavry'ata / B. M. Smy'ty’enko [y` dr.] ; pod red. B. M. Smy’ty’enko, N. V. Luk’yanovy`ch. - 3-e y`zd., per. y` dop. - M. : Y'zdatel'stvoYurajt, 2014. - $583 \mathrm{s.}$

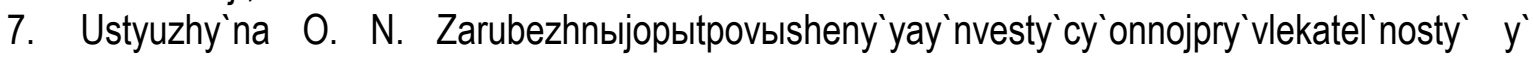
vozmozhnosty' ego pry'meneny'ya v Rossy'jskojFederacy'y' / O. N. Ustyuzhy'na. // Эkonomy 'ka y’ predpry'ny'matel'stvo. - 2014. - \#6. - S. 91-95.

8. Wissenschaftliches Investieren, Bank Sutor.-2016. [Electronic resource] - Access mode: https://www.anlage-wissen.de

9. Fy'lyuk G.M. Zarubizhny'j ta vitchy'znyany'j dosvid derzhavnoyi pidtry'mky' sil's'kogospodars 'ky'x vy' robny`kiv /G.M. Fy'lyuk, O.V. Pimenova // Visny`k Ky`yivs`kogo nacional'nogo universy tetu imeni Tarasa Shevchenka. - 2015. - \#5 (170). - S. 6-10.

10. Shevchenko N.I. Dosvid sy`stemy` derzhavnogo garantuvannya inozemnogo investuvannya $v$ rizny’x krayinax / N.I. Shevchenko // Ekonomika ta derzhava. - 2010. - \# 4. - S. 141-143.

11. K. Martinus. Investment and Trade: Drilling Down into Our Global Attractiveness / K. Martinus and Bo Guo// Factbase. Bulletin of the university of Western Australia. -2019. -\#65, - p. 1-12

12. S. Mustafakulov. Investment Attractiveness of Regions: Methodic Aspects of the Definition and Classification of Impacting Factors /S. Mustafakulov // European Scientific Journal. - 2017.- \#10, Vol.13.p. $433-448$

Акуленко К.В., аспірант

КНУ імені Тараса Шевченка

\section{АНАЛІЗ ЗАРУБІЖНОГО ДОСВІДУ ПІДВИЩЕННЯ ІНВЕСТИЦІЙНОЇ ПРИВАБЛИВОСТІ ПІДПРИЕМСТВ}

Досліджено концептуальні підходи до визначення економічної сутності поняття інвестиційної привабливості підприємства. Визначено переваги та виокремлено основні недоліки існуючих концепцій інвестиційної привабливості підприємства. Доповнено та узагальнено концепції дослідження сутності інвестиційної привабливості підприємства. Проаналізовано досвід розвинених зарубіжних країн щодо питань формування інвестиційної привабливості підприємств, а також галузей та регіонів загалом. Зокрема узагальнено зарубіжний досвід підвищення інвестищійної привабливості на прикладі США $і$ Китаю та розглянуті кластерні стратегії, що використовуються в європейських країнах.

Ключові слова: інвестиції,інвестиційна привабливість,інвестиційна привабливість підприємства, ефрективність інвестицій, задоволеність інвестора, зарубіжний досвід інвестиційної підтримки, кластерна модель. 
Акуленко Е.В., аспирант

КНУ имени Тараса Шевченко

\section{АНАЛИЗ ЗАРУБЕЖНОГО ОПЫТА ПОВЫШЕНИЯ ИНВЕСТИЦИОННОЙ ПРИВЛЕКАТЕЛЬНОСТИ ПРЕДПРИЯТИЯ}

Исследованы концептуальные подходы к определению экономической сущности понятия инвестиционной привлекательности предприятия. Определены преимущества и выделены основные недостатки существующих концепций инвестиционной привлекательности предприятия. Дополнены и обобщены концепции исследования сущности инвестиционной привлекательности предприятия. Проанализирован опыт развитых зарубежных стран по вопросам фрормирования инвестиционной привлекательности предприятий, а также отраслей и регионов в целом. $B$ частности обобщен зарубежный опыт повышения инвестиционной привлекательности на примере США и Китая и рассмотрены кластерные стратегии, используемые в европейских странах.

Ключевые слова: инвестиции, инвестиционная привлекательность, инвестиционная привлекательность предприятия, эфрфективность инвестиций, удовлетворенность инвестора, зарубежный опыт инвестиционной поддержки, кластерная модель. 